\title{
Hubungan antara Persepsi terhadap Kualitas dan Pemanfaatan Ruang Terbuka Hijau dengan Kesejahteraan Psikologis Anak
}

\author{
Relationship between Perception of Quality and Utilization of Green Open Space and \\ Child's Psychological Well-Being
}

\section{Afinnisa Rasyida ${ }^{1}$}

\begin{abstract}
Abstrak: Kabupaten Gresik merupakan wilayah yang tengah berusaha menerapkan kebijakan Ruang Terbuka Hijau (RTH) berupa taman ramah anak. Keberadaan RTH di Kabupaten Gresik sangatlah penting karena dapat berfungsi sebagai tempat bermain terbuka bagi anak dan juga penyaring polusi. Tujuan dari penelitian ini adalah untuk mengidentifikasi hubungan antara persepsi atas kualitas dan pemanfaatan RTH dengan kesejahteraan psikologis anak. Data dikumpulkan menggunakan skala persepsi atas kualitas dan pemanfaatan ruang terbuka hijau dan kuesioner kekuatan dan kesulitan yang didapat dari penilaian orang tua. Hasil penelitian menyebutkan bahwa terdapat hubungan antara persepsi atas kualitas dan pemanfaatan RTH dengan kesejahteraan psikologis anak pada dimensi kekuatan, yaitu dalam mengembangkan perilaku prososial. Hasil lainnya menyebutkan bahwa tidak terdapat hubungan antara persepsi atas kualitas dan pemanfaatan RTH dengan kesejahteraan psikologis anak pada dimensi kesulitan. Persepsi atas kualitas dan pemanfaatan RTH di Gresik sudah baik. Meski begitu, masyarakat masih merasakan minimnya faktor keamanan taman. Masyarakat juga masih jarang berkunjung ke taman. Hasil ini dapat dijadikan sebagai evaluasi bagi Pemerintah Daerah setempat untuk meningkatkan faktor keamanan dan kenyamanan taman.
\end{abstract}

Kata kunci: kesejahteraan psikologis anak, ruang terbuka hijau, taman ramah anak

\begin{abstract}
Gresik Regency has been trying to implement a green open space policy in the form of a child-friendly park. It is very substantial for Gresik Regency to have a park that can be both as outdoor space for children and also air pollution filter. This study aims to identify the relationship between perceptions of the quality and utilization of green open space with child psychological well-being. Data was collected using Perception of the Quality and Utilization of Green Open Space scale and Strength and Difficulties Questionnaire that obtained from parent's assessment. The results suggested that there was a relationship between the perception of the quality and utilization of green open space with the child's psychological well-being in the dimension of strength, specifically in developing prosocial behavior. However, there was no relationship in the dimension of difficulties. The results also obtained that the perception of the quality and utilization of green space in Gresik was good. Even so, the community still perceived the lack of park safety factors. They also infrequently visit the park. These results can be used as an evaluation for the Local Regional Government to improve the safety and comfort factor of the park.
\end{abstract}

Keywords: child-friendly parks, child psychological well-being, green open-space

\footnotetext{
${ }^{1}$ Fakultas Psikologi Universitas Surabaya
} 


\section{PENDAHULUAN}

Di zaman modern ini, pembangunan yang terjadi di Indonesia khususnya daerah perkotaan maupun pedesaan telah berkembang dengan pesat. Mayoritas lahan saat ini digunakan untuk perumahan, fasilitas hiburan, dan juga industri. Dengan perkembangan seperti ini, tidak dipungkiri bahwa saat ini semakin mudah kita lihat banyaknya pencemaran lingkungan dan terbatasnya lahan hijau di sekitar kita. Penelitian dari Lennon menyebutkan bahwa berbagai masalah lingkungan berdampak pada masalah ekonomi dan sosial sehingga kita perlu memiliki kebijakan dalam perencanaan kota dengan mempertimbangkan faktor kesehatan masyarakat sebagai faktor utama (Lennon, Douglas, \& Scott, 2017).

Dengan merebaknya fenomena ini, penelitian yang meneliti pengaruh lingkungan pada kesehatan fisik serta psikologis individu menjadi topik hangat yang diperbincangkan. Sayangnya, penelitian terdahulu menitikberatkan hanya terhadap kuantitas, seperti faktor kedekatan dan distribusi dari adanya ruang terbuka hijau. Seperti salah satu penelitian dari Kaczynski yang menyebutkan bahwa terdapat asosiasi positif antara meningkatnya aktivitas fisik dengan banyaknya ruang terbuka hijau yang lokasinya dekat dengan rumah (Kaczynski, Potwarka, \& Saelens P, 2008). Ketersediaan ruang terbuka hijau khususnya di perkotaan diharapkan dapat menjadi alternatif untuk menambah aktivitas fisik individu yang tinggal di sekitarnya. Ketika aktivitas fisik bertambah, maka kesempatan untuk meningkatkan kesehatan masyarakat juga dapat meningkat.

Kabupaten Gresik yang berlokasi di sebelah Barat Laut Kota Surabaya Provinsi Jawa Timur didominasi oleh banyaknya perusahaan berbasis industri seluas 12.448,026 hektar dan pertambangan seluas 817.249 hektar (Anonymous, 2013). Hal ini tentunya membuat kondisi wilayah Kabupaten Gresik menjadi sangat panas dan rawan polusi serta limbah. Karakteristik seperti ini membuat Pemerintah memerlukan sebuah strategi penyeimbang pembangunan berkelanjutan dimana diperlukan penataan ruang untuk menjaga kelestarian lingkungan hidup serta kesejahteraan masyarakatnya. Oleh karenanya, saat ini Kabupaten Gresik menjadi salah satu wilayah yang sedang berupaya menerapkan kebijakan wilayah ramah anak khususnya membuat taman ramah anak untuk mengatasi dampak-dampak yang muncul bagi lingkungan Kabupaten Gresik itu sendiri.

Ruang terbuka hijau didefinisikan sebagai semua ruang terbuka yang dimiliki publik dan dapat diakses publik dengan tingkat tutupan yang tinggi oleh vegetasi, seperti taman, hutan, area alam, dan ruang hijau lainnya di dalam area batas kota (Schipperijn, Bentsen, Troelsen, Toftager, \& Stigsdotter, 2013). Ruang terbuka hijau di perkotaan atau yang sering disebut dengan istilah urban green space memiliki kontribusi penting bagi masyarakat dengan menyediakan manfaat secara fisik, psikologis, sosial, ekonomi, dan tentunya lingkungan (Hunter et al., 2015). Saat ini di Indonesia, perencanaan taman kota untuk publik juga banyak didesain menjadi taman bermain dan memberikan fasilitasfasilitas bagi anak sampai dewasa. Taman dengan lebih banyak fasilitas lebih sering digunakan oleh masyarakat sekitarnya (Kaczynski et al., 2008).

Telah banyak diteliti manfaat yang diberikan ruang terbuka hijau terhadap manusia. Berbagai manfaat ini bervariasi baik bagi kesehatan fisik dan kesehatan psikis. Kelemahannya, hasilnya seringkali inkonsisten karena banyaknya faktor-faktor yang berkontribusi. Meskipun begitu, ruang terbuka hijau membuka akses bagi manusia untuk lebih banyak terpapar oleh lingkungan yang alami. Kontak dengan alam memiliki manfaat psikologis yang telah turun temurun dijelaskan oleh berbagai ahli, contohnya adalah dari Kaplan dan Ulrich. Kaplan yang mengembangkan teori restorasi atensi menyebutkan bahwa alam dapat memberikan rangsangan tertentu untuk memungkinkan individu melakukan pemulihan dari kelelahan yang terjadi selama melakukan tugas-tugas kognitif. 
Ulrich juga menyebutkan bahwa kontak dengan alam dapat memicu reaksi emosi positif (Bertram \& Rehdanz, 2015).

Kesejahteraan psikologis atau psychological well-being merupakan salah satu bahasan yang sangat popular di kalangan akademisi Psikologi. Beberapa ahli telah menyampaikan konsep yang jelas terkait hal ini, seperti salah satunya yang paling populer adalah Ryff. Kesejahteraan psikologis seringkali dikaitkan dengan konsep kebahagiaan, walaupun sebenarnya konsep ini merupakan konsep yang lebih kompleks. Seperti pada teori yang dipaparkan oleh Carol D. Ryff, kesejahteraan psikologis ditandai dengan adanya kemampuan dalam menerima diri, mengembangkan diri, memiliki tujuan hidup yang terarah, memiliki relasi positif dengan orang lain, memiliki kendali dan kompetensi dalam mengelola lingkungan, dan memiliki kemandirian (Ryff, 2013). Dengan memiliki kesejahteraan psikologis, maka seseorang akan dapat lebih sehat, hidup lebih lama, dan mampu menghadapi tantangan hidup (Diener \& Tay, 2015).

Penelitian yang mengaitkan antara ruang terbuka hijau dan kesejahteraan psikologis pada orang dewasa sudah banyak dilakukan, akan tetapi masih jarang penelitian yang mengaitkannya dengan kesejahteraan psikologis anak (Feng \& Astell-Burt, 2017). Hal ini patut menjadi perhatian karena jika sedari dini anak tidak dapat sejahtera dan tidak mendapat manfaat dari lingkungan sekitarnya, maka tidak menutup kemungkinan anak akan memunculkan gangguan perilaku di kemudian hari. Sebagai generasi penerus, maka hal ini juga akan berkontribusi secara negatif pula bagi wilayah tempat tinggalnya. Perlu diingat bahwa perkembangan anak sangatlah pesat dan hal ini dipengaruhi pula oleh paparan faktor-faktor yang ada lingkungan sekitar mereka.

Penelitian dari John H. McKendrick melaporkan bahwa lingkungan tempat tinggal berkontribusi dalam pembentukan dan peningkatan well-being anak. Kontribusi tersebut umumnya membahas mengenai adanya peluang lingkungan yang dapat memberikan ruang bermain dan memfasilitasi mobilitas mandiri anak (Ben-Arieh, Casas, Frønes, \& Korbin, E, 2014). Bermain di luar ruangan penting untuk perkembangan fisik, sosial, dan kognitif anak. Oleh karenanya, ketersediaan fasilitas dan akses untuk bermain di luar ruangan menjadi hal yang penting supaya anak dapat bermain dengan bebas di mana pun mereka tinggal. Bermain di luar ruangan dapat memunculkan rasa kesejahteraan dan kenikmatan (Shackell, Butler, Doyle, \& Ball, 2008). Hasil ini memberikan kita gambaran bahwa anak yang sering terpapar dengan ruang terbuka hijau akan menunjukkan kualitas hidup yang lebih baik. Mereka memiliki tempat untuk mengembangkan kemampuan motoriknya, khususnya motorik kasar seperti berlari. Meskipun begitu, kualitas dari taman bermain juga memegang peranan penting dalam memengaruhi kesejahteraan anak.

Goodman menyampaikan bahwa kesejahteraan anak memiliki lima dimensi (Goodman \& Goodman, 2009). Kelima dimensi ini mewakili dimensi strengths dan difficulties dalam kesejahteraan anak, yaitu conduct problem, emotional symptoms, hyperactive, peer problems, dan prosocial behavior. Dimensi yang termasuk strengths adalah perilaku prososial, sedangkan empat dimensi sisanya termasuk dimensi difficulties. Dimensi conduct problem ditandai dengan banyaknya perilaku anak yang bermasalah seperti bertengkar dengan anak lain atau mudah marah. Sementara itu, dimensi emotional symptoms merupakan tanda-tanda emosi anak yang cenderung negatif seperti mudah takut dan banyaknya kekhawatiran. Dimensi hyperactive ditandai dengan perilaku anak yang tidak terkendali, sulit diam dan perhatiannya mudah teralihkan. Dimensi peer problems membahas tentang adanya permasalahan anak dengan teman-teman sebayanya, seperti anak lebih suka menyendiri ataupun anak yang dirundung oleh anak lainnya. Satusatunya dimensi strengths dalam teori Goodman ditandai dengan adanya prosocial behavior. Dimensi prosocial behavior merupakan perilaku-perilaku prososial anak yang ditandai oleh perilaku anak yang suka menolong dan peduli dengan orang lain. Anak dikatakan sejahtera apabila ia memiliki banyak dimensi strengths yang berkembang dan sedikit masalah terkait dengan dimensi difficulties. 
Penting bagi Kabupaten Gresik untuk dapat mempertimbangkan penataan ruangnya dengan memperhatikan kesehatan fisik dan mental anak dalam upayanya membangun kota ramah anak. UNICEF sudah memperkenalkan konsep Kota Ramah Anak pada dunia. Kota ramah anak didefinisikan sebagai sebuah kota atau komunitas di mana pemerintahnya mengusahakan agar anak dapat hidup secara sehat tanpa kekerasan dalam lingkungan yang bersih dan aman dengan akses ke ruang hijau untuk bertemu teman dan bermain (UNICEF, 2013). Berdasarkan definisi tersebut, dapat disimpulkan bahwa salah satu syarat suatu tempat dinyatakan ramah anak adalah tersedianya ruang hijau yang aman dan ramah bagi anak untuk bermain, seperti taman bermain.

Australian Research Alliance for Children \& Youth (Wood, 2009) melaporkan beberapa karakteristik taman yang baik bagi anak. Karakteristik tersebut dilihat dari beberapa faktor seperti fitur, ukuran, keamanan, amenities, naungan, kondisi, akses, estetika, kedekatan dengan lalu lintas serta adanya peraturan dan regulasi yang jelas. Apabila masing-masing karakteristik ini dapat dipenuhi, maka taman atau ruang terbuka hijau ini akan mendorong adanya aktivitas fisik, interaksi sosial, kreativitas, pemecahan masalah serta interaksi langsung dengan alam yang baik bagi perkembangan dan kesejahteraan psikologis anak (Wood \& Martin, 2010). Oleh karenanya, Gresik dapat memanfaatkan ruang terbuka hijau untuk menjadi salah satu solusi bagi area paru-paru kota, penyerapan air, dan bahkan rekreasi masyarakat. Ruang terbuka hijau ramah anak dibuat dengan tujuan supaya masyarakat dapat melakukan aktivitas di luar ruangan bersama keluarga.

Berdasarkan penjelasan sebelumnya, maka penelitian ini ingin melihat sejauh mana usaha yang telah dilakukan Kabupaten Gresik membangun ruang terbuka hijau ramah anak diterima oleh masyarakat. Hal ini akan diukur melalui persepsi masyarakat terhadap kualitas serta pemanfaatan ruang terbuka hijau dan dikaitkan dengan kesejahteraan anak. Hasil penelitian ini dapat dijadikan rekomendasi khususnya bagi Pemerintah Daerah untuk merencanakan strategi pembangunan wilayah yang sesuai dengan kebutuhan dan kondisi lingkungan hidup dan masyarakatnya. Hipotesis dalam penelitian ini adalah:

H1: Terdapat hubungan antara ruang terbuka hijau dengan dimensi strengths pada kesejahteraan anak ditinjau dari perspektif orang tua.

H2: Terdapat hubungan antara ruang terbuka hijau dengan dimensi difficulties pada kesejahteraan anak ditinjau dari perspektif orang tua.

\section{METODE}

Penelitian ini menggunakan metode penelitian kuantitatif berbentuk survei. Terdapat dua variabel dalam penelitian, yaitu persepsi atas kualitas dan pemanfaatan ruang terbuka hijau sebagai variabel independen serta kesejahteraan psikologis anak sebagai variabel dependen. Partisipan dalam penelitian ini adalah para orang tua yang merupakan masyarakat Kabupaten Gresik yang tergabung dalam berbagai komunitas di Kabupaten Gresik. Pemilihan sampel menggunakan sampling aksidental. Partisipan yang mengisi kuesioner adalah para orang tua yang datang pada saat dilaksanakannya dua penyuluhan di Kabupaten Gresik.

Instrumen penelitian yang digunakan adalah dua kuesioner tertutup serta angket terbuka. Kuesioner tertutup serta angket terbuka dari variabel persepsi atas kualitas dan pemanfaatan ruang terbuka hijau diukur menggunakan kuesioner dan angket yang dikembangkan sendiri oleh peneliti dengan mengacu pada penelitian-penelitian sebelumnya di bidang serupa. Kuesioner kesejahteraan psikologis anak diukur menggunakan Strength and Difficulties Questionnaire dari Goodman (1997) yang telah diterjemahkan ke Bahasa Indonesia. Pengumpulan data dilakukan melalui survei yang disebarkan secara tatap muka. Pengumpulan data dilakukan pada bulan Oktober - 
November tahun 2019. Lokasi pengumpulan data dilakukan di Kabupaten Gresik tepatnya di Aula Kantor Kecamatan salah satu Kecamatan di Kabupaten Gresik serta di Kantor Bupati Gresik. Pertimbangan pemilihan lokasi ini berdasarkan rekomendasi dari Pemerintah Daerah Kabupaten Gresik. Data yang telah terkumpul lalu dianalisa menggunakan statistika deskriptif dan uji hipotesis korelasional Kendall. Analisa data dilakukan menggunakan SPSS versi 21.

Data penelitian yang terkumpul dari penelitian ini terdiri dari 138 partisipan yang seluruhnya berasal dari Kabupaten Gresik. Setelah ditelaah lebih lanjut, sebanyak 23 data tidak digunakan karena tidak lengkap dalam mengisi alat ukur yang diberikan. Oleh karenanya, data yang dapat digunakan untuk diolah adalah hanya dari 115 partisipan.

HASIL

Berdasarkan hasil dari 115 partisipan yang mengikuti penelitian ini, berikut akan dijelaskan data demografi yang terdapat pada tabel 1. Dari 115 partisipan, $94.8 \%$ adalah perempuan. Apabila dilihat dari usia, $42.6 \%$ didominasi oleh partisipan yang berusia 41 50 tahun. Sebanyak 48.7\% memiliki jenjang pendidikan Sarjana dengan pendapatan ratarata dengan pasangan dibawah UMR (56.5\%). Hampir semua partisipan (94.8\%) memiliki status menikah dengan jumlah anak 2 orang (59.1\%).

Tabel 1. Data Demografi Partisipan

\begin{tabular}{|c|c|c|c|}
\hline Data Demografi & & f & $\%$ \\
\hline \multirow[t]{3}{*}{ Jenis Kelamin } & Perempuan & 109 & 94,8 \\
\hline & Laki-laki & 2 & 1,7 \\
\hline & Tidak menjawab & 4 & 3,5 \\
\hline \multirow[t]{5}{*}{ Kecamatan } & Kebomas & 33 & 28,7 \\
\hline & Gresik & 25 & 21,7 \\
\hline & Wringinanom & 14 & 12,2 \\
\hline & Manyar & 10 & 8,7 \\
\hline & Lain-lain & 33 & 28,7 \\
\hline \multirow[t]{4}{*}{ Usia } & $>50$ & 26 & 22,6 \\
\hline & $41-50$ & 49 & 42,6 \\
\hline & $31-40$ & 30 & 26,1 \\
\hline & $20-30$ & 10 & 8,7 \\
\hline \multirow[t]{7}{*}{ Pendidikan } & Doktor & 1 & 0,9 \\
\hline & Magister & 1 & 0,9 \\
\hline & Sarjana & 56 & 48,7 \\
\hline & Diploma & 6 & 5,2 \\
\hline & SMA/sederajat & 38 & 33,0 \\
\hline & SMP/sederajat & 11 & 9,6 \\
\hline & SD & 2 & 1,7 \\
\hline \multirow[t]{2}{*}{ Suku Bangsa } & Jawa & 113 & 98,3 \\
\hline & Madura & 2 & 1,7 \\
\hline \multirow[t]{5}{*}{ Pendapatan/bulan } & Di atas UMR & 18 & 15,7 \\
\hline & UMR & 23 & 20,0 \\
\hline & Di bawah UMR & 65 & 56,5 \\
\hline & Lainnya & 2 & 1,7 \\
\hline & Tidak menjawab & 7 & 6,1 \\
\hline \multirow[t]{3}{*}{ Status } & Menikah & 109 & 94,8 \\
\hline & Tidak menikah & 2 & 1,7 \\
\hline & Lainnya & 4 & 3,5 \\
\hline \multirow[t]{3}{*}{ Jumlah Anak } & $\Rightarrow 3$ & 27 & 23,5 \\
\hline & 2 & 68 & 59,1 \\
\hline & 1 & 20 & 17,4 \\
\hline Total & & 115 & 100,0 \\
\hline
\end{tabular}

Sumber: Hasil Analisis Penulis, 2020 
Mayoritas jawaban partisipan atas persepsinya terhadap kualitas dan pemanfaatan ruang terbuka hijau masuk ke dalam kategori baik (73\%). Ini berarti, pandangan partisipan kepada ruang terbuka hijau yang ada di Kabupaten Gresik sudah baik. Hasil lebih lanjut dapat dilihat di Tabel 2.

Tabel 2. Kategori Skor Ruang Terbuka Hijau

\begin{tabular}{lcrrrr}
\hline Kategori & Batasan Nilai & f & \% & M & SD \\
\hline Sangat Baik & $\geq 62$ & 20 & 17,4 & 56,3518 & 5,24289 \\
Baik & $51-61$ & 84 & 73,0 & & \\
Cukup & $40-50$ & 11 & 9,6 & & \\
Tidak Baik & $28-39$ & 0 & 0,0 & & \\
Sangat Tidak Baik & $<28$ & 0 & 0,0 & & \\
\hline \multicolumn{1}{c}{ Total } & & 115 & 100,0 & & \\
\hline
\end{tabular}

Sumber: Hasil Analisis Penulis, 2020

Kesejahteraan anak diukur dari dua dimensi yaitu, strengths dan difficulties. Pada dimensi strengths, jawaban dari partisipan (ibu) memperlihatkan bahwa lebih dari setengah anak partisipan berada dalam kategori sangat baik (55,7\%). Ini berarti, kesejahteraan anak partisipan dalam hal strengths sudah sangat baik. Hasil lebih jelas dapat dilihat di tabel 3.

Tabel 3. Kategori Skor Kesejahteraan Anak (Strengths)

\begin{tabular}{lcrrrr}
\hline Kategori & Batasan Nilai & $\mathbf{f}$ & $\mathbf{\%}$ & M & SD \\
\hline Sangat Baik & $\geq 8$ & 64 & 55,7 & 7,6190 & 1,85815 \\
Baik & $6-7$ & 34 & 29,6 & & \\
Cukup & $4-5$ & 15 & 13,0 & & \\
Tidak Baik & $2-3$ & 1 & 0,9 & & \\
Sangat Tidak Baik & $<2$ & 1 & 0,9 & & \\
\hline \multicolumn{1}{c}{ Total } & & 115 & 100,0 & \\
\hline
\end{tabular}

Sumber: Hasil Analisis Penulis, 2020

Sementara itu, jika dilihat dari dimensi difficulties, maka dapat dilihat bahwa hampir separuh anak partisipan masuk ke dalam kategori baik $(47,8 \%)$. Ini berarti, kesejahteraan anak partisipan sudah bagus karena cenderung tidak memiliki kesulitan yang berpengaruh terhadap kesejahteraan anak. Hasil lebih jelas dapat dilihat di tabel 4 .

Tabel 4. Kategori Skor Kesejahteraan Anak (difficulties)

\begin{tabular}{lcrrrr}
\hline Kategori & Batasan Nilai & f & \% & M & SD \\
\hline Sangat Baik & $<8$ & 48 & 41,7 & 9,2601 & 4,88952 \\
Baik & $8-15$ & 55 & 47,8 & & \\
Cukup & $16-23$ & 12 & 10,4 & & \\
Tidak Baik & $24-31$ & 0 & 0,0 & & \\
Sangat Tidak Baik & $\geq 32$ & 0 & 0,0 & & \\
\hline \multicolumn{1}{c}{ Total } & & 115 & 100,0 & & \\
\hline
\end{tabular}

Sumber: Hasil Analisis Penulis, 2020

Hipotesis pertama dalam uji korelasi antara persepsi kualitas dan pemanfaatan ruang terbuka hijau dengan dimensi strengths pada kesejahteraan anak memperlihatkan hasil bahwa terdapat hubungan antara persepsi kualitas dan pemanfaatan ruang terbuka hijau dengan dimensi strengths pada kesejahteraan anak ditinjau dari perspektif orang tua. Hasil ini didapat dari hasil uji korelasi Kendall dengan nilai $\mathrm{p}<0,05$ sehingga hipotesis 1 diterima seperti tertera pada tabel 5 . 
Tabel 5. Hasil Uji Korelasi Hubungan antara Ruang Terbuka Hijau dengan Dimensi

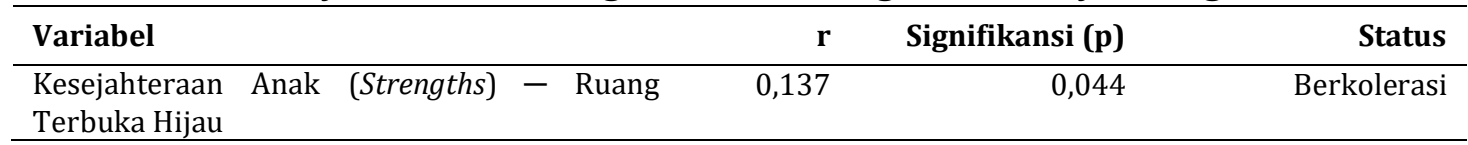

Sumber: Hasil Analisis Penulis, 2020

Hipotesis kedua dalam uji korelasi antara persepsi kualitas dan pemanfaatan ruang terbuka hijau dengan dimensi difficulties pada kesejahteraan anak memperlihatkan hasil bahwa tidak terdapat hubungan antara persepsi kualitas dan pemanfaatan ruang terbuka hijau dengan dimensi difficulties pada kesejahteraan anak ditinjau dari perspektif orang tua. Tabel 6 memaparkan hasil uji korelasi Kendall antara dimensi difficulties pada kesejahteraan anak dengan ruang terbuka hijau dan dapat dilihat bahwa nilai $p>0,05$ sehingga hipotesis 2 tidak diterima.

Tabel 6. Hasil Uji Korelasi Hubungan antara Ruang Terbuka Hijau dengan Dimensi Difficulties

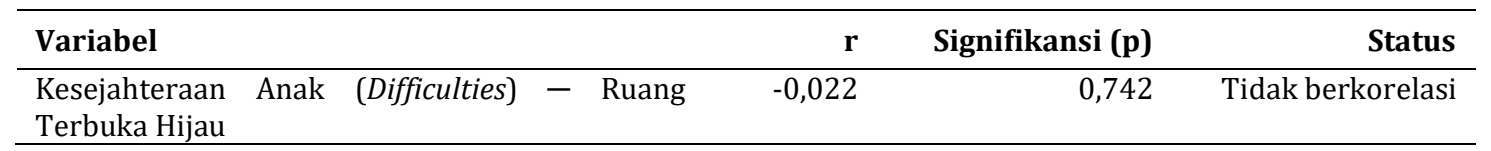

Sumber: Hasil Analisis Penulis, 2020

Terdapat beberapa pertanyaan terbuka yang diberikan pada orang tua untuk melengkapi penjelasan dari hasil kuesioner yang telah diberikan. Pertanyaan ini diberikan untuk memberikan gambaran yang lebih jelas mengenai persepsi atas kualitas dan pemanfaatan ruang terbuka hijau. Berikut akan disampaikan hasilnya di tabel 7 dan akan dibahas satu persatu.

Tabel 7. Data Angket Terbuka

\begin{tabular}{|c|c|c|c|}
\hline Keterangan & & $\mathbf{f}$ & $\%$ \\
\hline \multirow[t]{2}{*}{$\begin{array}{ll}\text { Pernah/Tidak } & \text { Pernah } \\
\text { Mengunjungi Taman } & \end{array}$} & Pernah & 109 & 94,8 \\
\hline & Tidak Pernah & 6 & 5,2 \\
\hline \multirow[t]{4}{*}{ Frekuensi kunjungan } & Sangat sering & 3 & 2,6 \\
\hline & Sering & 33 & 28,7 \\
\hline & Jarang & 68 & 59,1 \\
\hline & Sangat jarang & 11 & 9,6 \\
\hline \multirow[t]{5}{*}{ Lama kunjungan } & Di atas 2 jam & 1 & 0,9 \\
\hline & $1-2$ jam & 25 & 21,7 \\
\hline & 30-60 menit & 52 & 45,2 \\
\hline & 15-30 menit & 34 & 29,6 \\
\hline & Di bawah 15 menit & 3 & 2,6 \\
\hline \multirow[t]{5}{*}{ Kegiatan yang dilakukan } & Berjalan-jalan & 73 & 63,5 \\
\hline & Bermain & 51 & 44,3 \\
\hline & Berolahraga & 37 & 32,2 \\
\hline & Bertemu orang & 17 & 14,8 \\
\hline & Duduk-duduk & 62 & 53,9 \\
\hline \multirow[t]{4}{*}{ Dengan siapa ke taman } & Pasangan & 47 & 40,9 \\
\hline & Teman & 15 & 13,0 \\
\hline & Anak & 73 & 63,5 \\
\hline & Saudara & 9 & 7,8 \\
\hline \multirow[t]{7}{*}{ Hal yang disukai di taman } & Fitur/fasilitas/acaranya & 15 & 13,0 \\
\hline & Ukurannya & 8 & 7,0 \\
\hline & Keamanannya & 20 & 17,4 \\
\hline & $\begin{array}{l}\text { Kondisinya } \\
\text { perawatan) }\end{array}$ & 49 & 42,6 \\
\hline & Kemudahan aksesnya & 21 & 18,3 \\
\hline & Pemandangan/keindahannya & 73 & 63,5 \\
\hline & Lingkungan sekitarnya & 22 & 19,1 \\
\hline
\end{tabular}




\begin{tabular}{|c|c|c|c|}
\hline Keterangan & & $\mathbf{f}$ & $\%$ \\
\hline \multirow{5}{*}{ Alasan utama datang ke taman } & Kejelasan aturannya & 10 & 8,7 \\
\hline & Lainnya & 5 & 4,3 \\
\hline & Person & 80 & 69,6 \\
\hline & Environment nature & 34 & 29,6 \\
\hline & Environment park features & 54 & 47,0 \\
\hline \multirow[t]{9}{*}{ Karakteristik penting } & Fitur & 75 & 65,2 \\
\hline & Ukuran & 0 & 0,0 \\
\hline & Keamanan & 32 & 27,8 \\
\hline & Naungan & 16 & 13,9 \\
\hline & Kondisi & 64 & 55,7 \\
\hline & Akses & 3 & 2,6 \\
\hline & Estetika & 36 & 31,3 \\
\hline & Kedekatan dengan lalu lintas & 8 & 7,0 \\
\hline & Peraturan dan regulasi & 5 & 4,3 \\
\hline \multirow[t]{5}{*}{ Hal yang ditakutkan } & Person & 11 & 9,6 \\
\hline & Parkfeatures (keamanan alat) & 47 & 40,9 \\
\hline & $\begin{array}{l}\text { Park features (keamanan } \\
\text { lokasi) }\end{array}$ & 33 & 28,7 \\
\hline & $\begin{array}{l}\text { Park features (keamanan dari } \\
\text { orang asing/penculikan) }\end{array}$ & 31 & 27,0 \\
\hline & $\begin{array}{l}\text { Park features (perilaku orang } \\
\text { di lingkungan) }\end{array}$ & 11 & 9,6 \\
\hline \multirow[t]{9}{*}{$\begin{array}{l}\text { Karakteristik taman yang sudah } \\
\text { bagus }\end{array}$} & Fitur & 62 & 53,9 \\
\hline & Ukuran & 3 & 2,6 \\
\hline & Keamanan & 17 & 14,8 \\
\hline & Naungan & 15 & 13,0 \\
\hline & Kondisi & 25 & 21,7 \\
\hline & Akses & 6 & 5,2 \\
\hline & Estetika & 40 & 34,8 \\
\hline & Kedekatan dengan lalu lintas & 3 & 2,6 \\
\hline & Peraturan dan regulasi & 7 & 6,1 \\
\hline \multicolumn{2}{|l|}{ Total } & 115 & 100,0 \\
\hline
\end{tabular}

Sumber: Hasil Analisis Penulis, 2020

Pada pertanyaan pertama, peneliti ingin mengetahui pernahkah para ibu dan anak mengunjungi taman dengan tempat bermain anak. Hasil jawaban dari partisipan memperlihatkan hampir seluruh partisipan $(94,8 \%)$ pernah mengunjungi taman yang memiliki fasilitas tempat bermain anak. Jika dilihat dari frekuensi para ibu dan anak mengunjungi taman, hasil menyebutkan bahwa sebanyak 59,1\% partisipan masih jarang berkunjung ke taman. Terkait dengan durasi atau lamanya waktu partisipan mengunjungi taman dengan tempat bermain anak, hasil jawaban memperlihatkan bahwa mayoritas partisipan (45,2\%) menghabiskan waktu sekitar 30-60 menit saat berada di taman.

Pertanyaan keempat ingin mengetahui jenis kegiatan apa saja yang dilakukan partisipan saat mengunjungi taman dengan tempat bermain anak. Hasil memperlihatkan bahwa kegiatan yang biasa dilakukan oleh mayoritas partisipan ialah berjalan-jalan $(63,5 \%)$ dan lalu disusul dengan bermain $(44,3 \%)$ di taman. Partisipan juga menyebutkan bahwa anak adalah orang yang paling sering diajak partisipan untuk pergi ke taman $(63,5 \%)$. Selain itu, partisipan juga sering mengajak pasangan $(40,9 \%)$. Terkait dengan hal atau faktor apa yang disukai dari taman dengan tempat bermain anak, partisipan menyebutkan bahwa sebanyak 63,5\% partisipan menyukai pemandangan/keindahan dari suatu taman. Selain itu, kondisi taman seperti kebersihan dan perawatan juga menjadi pilihan terbanyak kedua $(42,6 \%)$.

Alasan utama partisipan datang ke taman ialah karena faktor person $(69,6 \%)$. Faktor person disini artinya alasan yang diberikan atas dasar kebutuhan partisipan itu sendiri seperti hal-hal yang berhubungan dengan fisik (contohnya jalan-jalan dan 
bersantai). Alasan terbanyak kedua ialah faktor park features (47\%). Partisipan menyukai taman yang memiliki banyak fasilitas seperti salah satunya fasilitas taman bermain. Alasan terbanyak ketiga ialah faktor nature $(29,6 \%)$. Faktor nature disini merujuk pada keindahan lingkungan yang alami dan memiliki banyak pepohonan atau vegetasi lain di sekitar taman.

Menurut partisipan, hal yang dianggap paling penting untuk dimiliki suatu taman agar menjadi taman yang ramah anak ialah fitur (75\%) yang lalu diikuti dengan kondisi (55,7\%). Artinya, partisipan merasa sebuah taman perlu memiliki fitur yang lengkap. Tidak hanya itu, taman pun perlu memiliki kondisi yang kondusif untuk melakukan berbagai macam kegiatan di area tersebut.

Beberapa kekurangan dan kelebihan dari taman pun ditanyakan di angket terbuka. Salah satu kekurangannya adalah masih banyaknya rasa takut terhadap hal-hal yang ada di taman. Hasil penelitian ini menyebutkan bahwa terdapat 40,9\% partisipan yang takut dengan faktor keamanan taman, baik dari segi keamanan alat seperti kondisi alatnya, segi keamanan lokasi seperti pengawasan lingkungan sekitar taman (28,7\%), maupun segi orang asing seperti ketakutan adanya orang asing yang melakukan penculikan (27\%). Sementara itu, menurut kebanyakan partisipan, faktor fitur $(53,9 \%)$ merupakan hal yang sudah baik di taman agar menjadi ramah anak. Selain itu, faktor estetika $(34,8 \%)$ juga dipilih menjadi hal yang sudah baik di taman agar menjadi taman ramah anak. Artinya, partisipan merasa taman yang tersedia sudah bagus karena fiturnya yang cukup lengkap dan memiliki nilai estetik sehingga dapat memanjakan mata.

Di akhir pertanyaan terbuka, partisipan juga ditanya mengenai tempat yang paling aman untuk anak di Kabupaten Gresik. Banyak partisipan yang tidak menyebutkan secara spesifik nama tempatnya, namun ada beberapa partisipan yang menyebutkan Alon-Alon Kota Gresik (9,6\%) sebagai tempat yang aman untuk anak. Selain tempat yang aman, partisipan juga ditanya mengenai tempat yang paling ramah anak di Kabupaten Gresik. Kembali banyak partisipan tidak menyebutkan secara spesifik nama tempatnya, tetapi sebanyak 12,2\% partisipan menyebutkan Taman Gresik Kota Baru dan Alon-Alon Kota Gresik (11,3\%) sebagai tempat yang paling ramah anak di Kabupaten Gresik.

\section{PEMBAHASAN}

Penelitian ini memiliki dua hipotesis. Melalui penelitian ini, ditemukan hasil bahwa ruang terbuka hijau memiliki hubungan positif signifikan dengan dimensi strengths pada kesejahteraan anak yang ditinjau dari perspektif orang tua. Walaupun begitu, ruang terbuka hijau tidak memiliki hubungan dengan dimensi difficulties pada kesejahteraan anak yang ditinjau dari perspektif orang tua.

Ruang terbuka hijau berkorelasi positif dengan dimensi strengths pada kesejahteraan anak $(r=0,137 ; p=0,044)$. Dimensi strengths pada kesejahteraan anak ini memiliki satu aspek, yaitu perilaku prososial. Hasil ini sejalan dengan penelitian milik McEachan yang melaporkan bahwa kepuasan akan ruang hijau merupakan prediktor independen perilaku prososial yang merupakan dimensi strengths pada kesejahteraan anak (McEachan et al., 2018). Artinya, apabila kepuasan orang tua terhadap kualitas ruang terbuka hijau bertambah, maka tidak menutup kemungkinan hal ini dapat meningkatkan perilaku prososial anak. Perilaku prososial dapat diartikan sebagai perilaku positif yang dimulai dari adanya hasrat atau keinginan untuk menolong orang lain tanpa memikirkan diri atau kepentingannya sendiri (Myers, 2010). Perilaku prososial pada anak dapat dilihat dari tindakan anak dalam bermain, seperti berbagi mainan, bekerja sama dalam sebuah kelompok, dan menolong teman yang sedang kesulitan. Jika orang tua puas terhadap keberadaan taman, khususnya taman dengan fasilitas bermain anak, maka mereka dapat mengajak anaknya untuk bermain disana. 
Perilaku prososial berkaitan dengan ruang hijau alami di lingkungan. Ini berarti, ruang publik memiliki peran penting dalam memfasilitasi interaksi yang menguntungkan secara sosial karena adanya anak-anak lain yang berada pada tempat tersebut (Richardson, Pearce, Shortt, \& Mitchell, 2017). Taman menjadi salah satu fasilitas yang dapat dipergunakan oleh masyarakat umum dan membantu anak untuk memperlihatkan dan mengembangkan perilaku prososial. Anak menjadi terfasilitasi dan mendapat kesempatan untuk mengembangkan banyak interaksi, khususnya dalam mengembangkan perilaku prososial. Menurut teori, perilaku prososial pada anak sudah mulai ditunjukkan sejak tahun ke-3 kehidupan. Perilaku prososial pada anak antara lain terbagi menjadi membantu orang lain mencapai tujuan mereka, menanggapi kebutuhan emosional orang lain, dan berbagi sumber daya (Chernyak, Harvey, Tarullo, Rockers, \& Blake, 2018). Hal ini tentunya dapat dilakukan dan dikembangkan ketika anak sedang bermain di taman.

Hipotesis kedua menyebutkan bahwa ruang terbuka hijau tidak berkorelasi dengan dimensi difficulties pada kesejahteraan anak. Dimensi difficulties pada kesejahteraan anak memiliki empat aspek, yaitu conduct problem, emotional symptoms, hyperactive, dan peer problems. Artinya, pemanfaatan ruang terbuka hijau sebenarnya tidak berhubungan dengan adanya masalah emosi dan perilaku pada anak seperti aspekaspek diatas. Seperti yang kita tahu, anak dapat mengembangkan masalah emosi dan perilaku. Walaupun begitu, kemunculan masalah ini dapat dipengaruhi oleh banyak faktor. Apabila kita melihat masalah ini dari perspektif kesehatan psikologis, maka kemunculan masalah emosi dan perilaku anak dapat muncul dari interaksi antara faktor yang ada dalam diri anak, faktor keluarga dan faktor lingkungan (Thompson et al., 2012). Faktor dalam diri anak terdiri dari faktor biologis (genetik, kesehatan, dll), psikologis (temperamen, kebiasaan, konsep diri, dll), dan sosial (hubungan dengan orang tua, kondisi ekonomi, dll). Sementara itu, faktor keluarga menyangkut kondisi yang ada di keluarga seperti pola asuh, kelekatan, dan struktur keluarga. Faktor lingkungan pun masih terdiri dari banyak aspek, seperti karakteristik orang-orang di lingkungan sekitar anak, kondisi fisik, lingkungan, kondisi ekonomi, dan kondisi lainnya terkait norma dan moral (Thompson et al., 2012).

Hasil dari penelitian-penelitian terdahulu mengenai ruang terbuka hijau dan kesejahteraan anak khususnya pada dimensi difficulties ini sebenarnya masih memiliki hasil yang tidak konsisten. Kemungkinan hal ini disebabkan oleh penggunaan alat ukur ruang terbuka hijau yang berbeda-beda (McEachan et al., 2018). Hasil penelitian ini tidak sejalan dengan penelitian milik Amoly yang menemukan bahwa ruang terbuka hijau memiliki asosiasi negatif dengan total dimensi difficulties pada kesejahteraan anak (Amoly et al., 2014). Meskipun begitu, memang ada baiknya apabila dalam menilai kesejahteraan anak kita perlu melihatnya secara menyeluruh. Penggambaran atau identifikasi dari satu faktor saja misal faktor lingkungan akan menghasilkan data yang prematur.

Menurut Feng, kebanyakan penelitian sebelumnya mengenai ruang terbuka hijau dan kesejahteraan anak berfokus pada kuantitas ruang hijau (Feng \& Astell-Burt, 2017). Ada juga penulis yang menyarankan bahwa kualitas ruang hijau dapat berperan sebagai faktor mediator yang berarti asosiasi antara kuantitas ruang hijau dan kesehatan lebih kuat ketika kualitas juga tinggi (McEachan et al., 2018). Melihat hasil dari beberapa penelitian tersebut, penelitian ini ingin pula menggali data yang memperlihatkan kualitas dari ruang terbuka hijau. Kualitas ruang terbuka hijau didapat dari persepsi orangtua terhadap kualitas ruang terbuka hijau yang ada di lingkungannya serta beberapa data dari angket terbuka. Hal ini penting karena kepuasan akan kualitas ruang hijau merupakan prediktor kesejahteraan yang lebih penting bila dibandingkan dengan kuantitas ruang hijau bagi orangtua dari daerah Asia Selatan (McEachan et al., 2018). Penelitian dari McEachan ini memiliki subjek yang berasal dari Indonesia dan negara lainnya di Asia Tenggara. Hasilnya, kualitas ruang terbuka hijau didapati berkorelasi positif dengan dimensi strengths dari kesejahteraan anak. Alam memiliki dampak positif seperti 
pengembangan fungsi kognitif, koordinasi motorik yang lebih baik, menurunkan tingkat stres, meningkatkan interaksi sosial baik dengan orang dewasa maupun anak-anak lain serta meningkatkan kecakapan sosial (Davis \& Johnson, 2016).

Hasil studi Maas juga melaporkan bahwa pengembangan kontak sosial yang didapatkan saat berada dalam ruang hijau dapat meningkatkan kesehatan psikologis (Maas et al., 2009). Hasil studinya menunjukkan bahwa orang-orang dengan pendapatan rendah atau edukasi yang rendah mendapatkan keuntungan dari ruang hijau untuk kontak sosialnya. Jika dilihat dari data demografis partisipan, mayoritas partisipan pada penelitian ini memiliki pendapatan di bawah UMR (56,5\%), yang berarti pendapatannya tergolong rendah. Oleh karenanya, masyarakat di kalangan ini sebenarnya mendapatkan keuntungan yang besar apabila disekitar lingkungan mereka terdapat ruang terbuka hijau yang memiliki banyak fitur untuk menunjang kesehatan psikologis mereka.

Tabel 2 menunjukkan bahwa persepsi akan kualitas dan pemanfaatan ruang terbuka hijau di Gresik sudah baik (73\%). Artinya, Kabupaten Gresik yang saat ini sudah menerapkan kebijakan wilayah ramah anak sudah dapat diterima dan diapresiasi oleh masyarakat. Pada tabel 3, dapat dilihat bahwa kesejahteraan anak yang dimiliki oleh kebanyakan partisipan $(55,7 \%)$ sudah berada pada kategori sangat baik pada dimensi strengths. Hal ini juga dapat memperkuat asumsi bahwa Kabupaten Gresik sangat peduli dengan kondisi anak dan sudah berhasil dalam mengembangkan wilayah ramah anak.

Hasil penelitian menyebutkan bahwa partisipan banyak menggunakan taman untuk berjalan-jalan (63,5\%) dan bermain (44,3\%). Hal ini sesuai dengan Model for Person-Environment-Health Relationship milik Irvine (Irvine, Warber, Devine-wright, \& Gaston, 2013). Model ini menggambarkan motivasi seseorang untuk pergi ke taman beserta manfaatnya. Berjalan-jalan dan bermain merupakan motivasi untuk pergi ke taman pada person level. Berjalan-jalan termasuk dalam bidang physical, sedangkan bermain termasuk dalam bidang children. Sejalan dengan tabel 7, alasan utama partisipan datang ke taman terletak pada level person (69,6\%). Selain pada person level, motivasi seseorang untuk pergi ke taman dapat ditinjau dari environment level. Tabel 7 menunjukkan bahwa partisipan menyukai pemandangan/keindahan dari taman $(63,5 \%)$. Pemandangan termasuk dalam bidang nature pada environment level. Kebanyakan partisipan $(63,5 \%)$ juga beraktivitas di taman bersama anaknya. Jadi dapat disimpulkan bahwa biasanya partisipan pergi ke taman bersama anaknya untuk berjalan-jalan dan bermain.

Australian Research Alliance for Children \& Youth dalam laporannya menjabarkan beberapa karakteristik yang dapat menggambarkan taman ramah anak (Wood, 2009). Berdasarkan karakteristik tersebut, mayoritas peserta setuju bahwa fitur $(65,2 \%)$ dan kondisi $(55,7 \%)$ merupakan hal penting untuk dimiliki taman agar menjadi ramah anak. Fitur berarti kelengkapan fasilitas untuk anak di taman, sedangkan kondisi mengacu pada keadaan dari taman itu baik dari segi fasilitasnya maupun taman itu sendiri secara fisik. Kualitas ruang terbuka hijau di Gresik yang sudah tergolong baik (tabel 2) disebabkan oleh partisipan yang mengganggap fitur di taman sudah baik dan ramah anak seperti tersedianya fasilitas bermain anak. Tak hanya fitur, estetika juga sudah dianggap bagus oleh partisipan dan merupakan hal yang paling disukai dari sebuah taman.

Kelemahan yang masih perlu menjadi pertimbangan di Kabupaten Gresik adalah terkait partisipan yang masih jarang menggunakan taman yang tersedia (tabel 18; 59,1\%). Waktu yang dihabiskan di taman pun tidak terlalu lama, yakni sekitar 30-60 menit (tabel $19 ; 45,2 \%)$. Perlu penelitian lanjutan untuk dapat menggali perilaku ini supaya kedepannya apa yang sudah dipersiapkan oleh pemerintah daerah setempat dapat dimanfaatkan secara maksimal oleh masyarakat sekitarnya.

Selain kedua hal diatas, partisipan juga mengaku bahwa mereka paling takut dengan keamanan dari alat-alat permainan yang ada di taman tersebut. Partisipan mengkhawatirkan kondisi dan perawatan akan fasilitas yang ada, serta kecocokan alat 
permainan tersebut untuk anak mereka. Mereka paling takut bila anak mereka terluka karena alat-alat tersebut. Hasil ini serupa dengan penelitian Strife dimana kekhawatiran orangtua tentang keselamatan anak, meningkatnya hiburan yang dapat dilakukan dalam ruangan serta meningkatnya urbanisasi dapat berkontribusi pada berkurangnya pengalaman alam anak (Davis \& Johnson, 2016). Pengalaman alam anak yang berkurang tentunya akan memberikan dampak yang cukup signifikan. Penelitian lanjutan dapat membandingkan kondisi kesejahteraan anak sesuai dengan fenomena anak pada generasi saat ini yang lebih banyak menghabiskan waktu dan bermain dengan gadget-nya. Bahkan permainan dan olahraga yang dulu hanya ada dalam bentuk permainan langsung, sekarang banyak dibuat versi games-nya.

Satu hal penting yang seringkali terlupakan adalah perencanaan tata kota yang menyeluruh, tidak hanya pada perencanaan pembuatan namun perencanaan untuk perawatan. Disini pemerintah daerah memerlukan kebijakan perencanaan kota yang dapat memastikan anak-anak memiliki akses terdekat ke alam yang dapat membantu meningkatkan perkembangan anak (Richardson et al., 2017). Gresik sebagai Kota yang sedang menerapkan prinsip ruang terbuka hijau dengan bentuk taman ramah anak sebenarnya dinilai oleh partisipan sudah cukup berhasil dalam mewujudkan hal tersebut. Partisipan menyebutkan Alon-Alon Kota Gresik (9,6\%) sebagai tempat yang menurut mereka aman bagi anak. Partisipan juga menyebutkan Taman Gresik Kota Baru $(12,2 \%)$ dan Alon-Alon Kota Gresik (11,3\%) sebagai tempat yang sudah ramah anak. Artinya, kebijakan pemerintah kota Gresik sudah mulai dipandang positif dan dimanfaatkan oleh masyarakat. Tentunya hal ini perlu dipertahankan khususnya dalam melakukan perawatan atas fasilitas yang sudah ada dan pengembangan atau peningkatan jumlah RTH ramah anak kelak.

\section{KESIMPULAN}

Persepsi atas kualitas ruang terbuka hijau dan pemanfaatannya memiliki hubungan dengan dimensi strengths pada kesejahteraan anak ditinjau dari perspektif orangtua. Artinya, apabila kepuasan orang tua dan pemanfaatan ruang terbuka hijau bertambah, maka hal ini dapat meningkatkan kesejahteraan anak melalui meningkatnya perilaku prososial pada anak. Sementara itu, persepsi atas kualitas ruang terbuka hijau dan pemanfaatannya tidak memiliki hubungan dengan dimensi difficulties pada kesejahteraan anak ditinjau dari perspektif orangtua. Artinya, kualitas serta pemanfaatan ruang terbuka hijau tidak berhubungan dengan adanya masalah emosi dan perilaku pada anak. Secara umum, kesejahteraan anak partisipan pada penelitian ini sudah tergolong baik. Persepsi atas kualitas ruang terbuka hijau di Kabupaten Gresik oleh partisipan penelitian juga sudah tergolong baik, dengan jawaban dari mayoritas partisipan masuk ke dalam kategori baik. Bagi partisipan, taman yang memiliki fitur untuk anak yang lengkap dan kondisi yang baik merupakan hal terpenting.

Hasil juga memperlihatkan bahwa partisipan masih jarang menggunakan taman yang tersedia dan paling mengkhawatirkan keamanan alat yang ada di taman. Hasil ini dapat menjadi sebuah evaluasi bagi Pemerintah Daerah Kabupaten Gresik dan Dinas yang berhubungan untuk dapat meningkatkan kualitas dari ruang terbuka hijau yang ada. Perlu adanya sinkronisasi pembagian tugas pengawasan RTH dari pemerintah setempat supaya dapat meningkatkan faktor keamanan taman. Penambahan fasilitas seperti CCTV dan zebra cross dapat menjadi pilihan. Perawatan terhadap alat-alat atau mainan yang ada di taman juga sebaiknya dapat dijalankan secara rutin dan konsisten. Mengingat pemanfaatan dan kunjungan ke RTH di masyarakat masih rendah, maka diperlukan pula penambahan fasilitas yang dapat meningkatkan kenyamanan taman. Nilai estetika dari taman juga perlu lebih dipertimbangkan mengingat masyarakat menginginkan adanya keindahan alam yang masih dapat mereka rasakan walaupun berada di tengah kota. 


\section{UCAPAN TERIMA KASIH}

Penulis ingin mengucapkan banyak terima kasih kepada Pemerintah Daerah Kabupaten Gresik, Dinas Lingkungan Hidup Kabupaten Gresik serta Dinas Keluarga Berencana, Pemberdayaan Perempuan dan Perlindungan Anak (KBPP) Kabupaten Gresik yang telah banyak memberikan kontribusi sehingga penulis dapat menyelesaikan penelitian ini.

\section{DAFTAR PUSTAKA}

Amoly, E., Payam, D., Forns, J., López-Vicente, M., Basagaña, X., Julvez, J., ... Sunyer, J. (2014). Green and blue spaces and behavioral development in Barcelona schoolchildren: The BREATHE Project. Children's Health, 122(12), 1351-1358.

Anonymous. (2013). Kabupaten Gresik: Potensi dan Produk Unggulan Jawa Timur. Retrieved from http://bappeda.jatimprov.go.id/bappeda/wp-content/uploads/potensi-kab-kota-2013/kab-gresik2013.pdf

Ben-Arieh, A., Casas, F., Frønes, I., \& Korbin, E, J. (2014). Handbook of Child Well-Being Theories, Methods and Policies in Global Perspective. In Handbook of Child Well-Being (Vol. 26). https://doi.org/10.1007/97894-007-7208-3

Bertram, C., \& Rehdanz, K. (2015). The role of urban green space for human well-being. Ecological Economics, 120(2015), 139-152. https://doi.org/10.1016/j.ecolecon.2015.10.013

Chernyak, N., Harvey, T., Tarullo, A. R., Rockers, P. C., \& Blake, P. R. (2018). Varieties of young children's prosocial behavior in Zambia: The role of cognitive ability, wealth, and inequality beliefs. Frontiers in Psychology, 9(NOV), 1-10. https://doi.org/10.3389/fpsyg.2018.02209

Davis, K. G., \& Johnson, C. D. (2016). Childhood Development and Behavior. Pediatric Clinics of North America, 63(5), i. https://doi.org/10.1016/s0031-3955(16)41065-5

Diener, E., \& Tay, L. (2015). Subjective well-being and human welfare around the world as reflected in the Gallup World Poll. International Journal of Psychology, 50(2), 135-149. https://doi.org/10.1002/ijop.12136

Feng, X., \& Astell-Burt, T. (2017). The relationship between neighbourhood green space and child mental wellbeing depends upon whom you ask: Multilevel evidence from 3083 children aged 12-13 years. International Journal of Environmental Research and Public Health, 14(3). https://doi.org/10.3390/ijerph14030235

Goodman, A., \& Goodman, R. (2009). Strengths and difficulties questionnaire as a dimensional measure of child mental health. Journal of the American Academy of Child and Adolescent Psychiatry, 48(4), 400-403. https://doi.org/10.1097/CHI.0b013e3181985068

Hunter, R. F., Christian, H., Veitch, J., Astell-burt, T., Hipp, J. A., \& Schipperijn, J. (2015). The impact of interventions to promote physical activity in urban green space: A systematic review and recommendations for future research. Social Science \& Medicine, 124, 246-256. https://doi.org/10.1016/j.socscimed.2014.11.051

Irvine, K. N., Warber, S. L., Devine-wright, P., \& Gaston, K. J. (2013). Understanding Urban Green Space as a Health Resource : A Qualitative Comparison of Visit Motivation and Derived Effects among Park Users in Sheffield , UK. 417-442. https://doi.org/10.3390/ijerph10010417

Kaczynski, A. T., Potwarka, L. R., \& Saelens P, B. E. (2008). Association of park size, distance, and features with physical activity in neighborhood parks. American Journal of Public Health, 98(8), 1451-1456. https://doi.org/10.2105/AJPH.2007.129064

Lennon, M., Douglas, O., \& Scott, M. (2017). Urban green space for health and well-being: developing an ' affordances ' framework for planning and design. Journal of Urban Design, (April). https://doi.org/10.1080/13574809.2017.1336058

Maas, J., Verheij, R. A., De Vries, S., Spreeuwenberg, P., Schellevis, F. G., \& Groenewegen, P. P. (2009). Morbidity is related to a green living environment. Journal of Epidemiology and Community Health, 63(12), 967973. https://doi.org/10.1136/jech.2008.079038

McEachan, R. R. C., Yang, T. C., Roberts, H., Pickett, K. E., Arseneau-Powell, D., Gidlow, C. J., ... Nieuwenhuijsen, M. (2018). Availability, use of, and satisfaction with green space, and children's mental wellbeing at age 4 years in a multicultural, deprived, urban area: results from the Born in Bradford cohort study. The Lancet Planetary Health, 2(6), e244-e254. https://doi.org/10.1016/S2542-5196(18)30119-0

Myers, D. G. (2010). Social Psychology (Tenth Edit). New York: McGraw-Hill. 
Richardson, E. A., Pearce, J., Shortt, N. K., \& Mitchell, R. (2017). The role of public and private natural space in children's social, emotional and behavioural development in Scotland: A longitudinal study. Environmental Research, 158(October 2016), 729-736. https://doi.org/10.1016/j.envres.2017.07.038

Ryff, C. D. (2013). Psychological well-being revisited: Advances in the science and practice of eudaimonia. Psychotherapy and Psychosomatics, 83(1), 10-28. https://doi.org/10.1159/000353263

Schipperijn, J., Bentsen, P., Troelsen, J., Toftager, M., \& Stigsdotter, U. K. (2013). Associations between physical activity and characteristics of urban green space. Urban Forestry and Urban Greening, 12(1), 109-116. https://doi.org/10.1016/j.ufug.2012.12.002

Shackell, A., Butler, N., Doyle, P., \& Ball, D. (2008). Design for Play: A guide to creating successful play spaces. Department for Culture, Media and Sport Department for Children, Schools and Families, 156. Retrieved from http://eprints.mdx.ac.uk/5028/\%0Awww.playengland.org.uk

Thompson, M., Hooper, C., LaverBradbury, C., \& Gale, C. (2012). Child and Adolescent Mental Health: Theory and Practice, 2nd Edition. Child and Adolescent Mental Health: Theory and Practice, 2Nd Edition, 1-518.

UNICEF. (2013). UNICEF Child Friendly Cities and Communities Handbook. 68.

Wood, L. (2009). Action for Young Australians Report: Parks and open space: for the health and wellbeing of children and young people.

Wood, L., \& Martin, K. (2010). What makes a good play area for children ? Centre for the Built Environment and Health, 1-8. Retrieved from http://www.web.uwa.edu.au/_data/assets/pdf_file/0011/1857467/What-makes-a-good-play-arealiterature-summaryfeb2011.pdf 